\title{
Os limites do enunciado apofântico \\ e a posição ontológica da lógica: uma \\ interpretação do $\$ 33$ de Sein und Zeit
}

\section{The limits of the apophantic judgment and the ontological}

position of logic: an interpretation of Sein und Zeit's $\mathbf{S 3 3}$

Dndo. Felipe Maia da Silva felipemaia_lee@hotmail.com Universidade de São Paulo

O $\$ 33$ cumpre um papel central na analítica existencial do Dasein em Sein und Zeit, uma vez que introduz a destruição fenomenológica do conceito tradicional - lógico - de lógos, preparando o caminho para uma análise construtiva da Rede. Nosso objetivo neste artigo é expor as principais camadas argumentativas desta destruição lógico-ontológica ali presente, que apontam justamente para os limites ou as origens existenciais do enunciado apofântico (Aussage), realçando, paralelamente, o diálogo velado de Heidegger com a tradição - e especialmente com Aristóteles.

\section{PALAVRAS-ChaVe Enunciado. Logos. Ontologia. Fenomenologia. \\ Heidegger. Aristóteles}

The paragraph 33 has a central role inside the existential analytic of Dasein in Sein und Zeit, since it introduces the phenomenological destruction of the traditional - logical - concept of logos, thus paving the way to a constructive analysis of Rede. Our purpose in this article is to expose the main argumentative levels of that logical-ontological destruction, which points precisely to the limits or the existential origins of the apophantic judgment (Aussage), emphasizing simultaneously the veiled dialogue between Heidegger and the tradition - especially with Aristotle. 
No $§ 33$ de Sein und Zeit, intitulado $O$ enunciado como modo derivado da interpretação - explicitamente proveniente do campo de reflexões do parágrafo anterior e preparatório do importante $\$ 34$-, Heidegger desdobra mais uma vez na obra a reflexão sobre a necessidade de estabelecimento de um diverso nexo de fundamentação (Fundierungszusammenhang) na consideração filosófica dos comportamentos imediatos do Dasein e dos modos de ser deles decorrentes. O tema é tratado ali particularmente no horizonte crítico da destruição fenomenológica do conceito tradicional de articulação da linguagem, que teria estabelecido no lógos apofântico seu paradigma. Nesse sentido, a lógica predicativa é exposta por Heidegger, com base no novo nexo de fundamentação proposto, como ontologicamente derivada e seu papel monopolizante na consideração do 'linguístico' é apresentado como consequência da interpretação metafísica sobre o sentido do lógos. A estrutura-como apofântica dos juízos, encontrando suas raízes nas elaborações hermenêuticas prévias da existência (o como-hermenêutico), é abordada por Heidegger neste recorte da obra especialmente a partir de um velado contexto aristotélico. Acompanharemos alguns pontos dessa discussão, indicando o sentido da retomada aristotélica de Heidegger e da paralela pretensão de radicalização do filósofo grego. Para tanto, propomos preliminarmente uma interpretação ampla do §33, realçando sua função no interior da obra de 1927 e sua relação de fundo com certos seminários do período.

\section{O §33 de Sein und Zeit}

O $\$ 33$ de Sein und Zeit descreve o papel derivado do enunciado judicativo (Aussage - Urteil) em relação ao modo de articulação encontrado na interpretação existencial (Auslegung) (HEIDEGGER, 2006a, §32). Após estudarmos as nuances dessa derivação, nossa exposição se concentrará no significado crítico desta inversão de perspectiva. No fim do parágrafo, Heidegger revela o sentido amplo da exposição precedente, explicitando suas intenções:

por enquanto, trata-se apenas de tornar claro, com a atestação do caráter derivado do enunciado diante da interpretação e do compreender, o fato de que a 'lógica' do lógos se enraíza na analítica existencial do Dasein. O conhecimento da insuficiente interpretação ontológica do lógos torna mais aguda a percepção da 
Os limites do enunciado apofântico e a posição ontológica da lógica: uma interpretação do §33 de Sein und Zeit
Dndo. Felipe Maia

da Silva [USP]

base metodológica não-originária sobre a qual a antiga ontologia se erigiu (HEIDEGGER, 2006a, p. 160)ํ․

Para além de tal crítica da ontologia, à qual retornaremos na segunda metade deste texto, o autor julga que a investigação sobre o caráter derivado do enunciado também pode eventualmente tornar mais claro em que sentido o 'como' articulador desdobra-se na consumação da existência do Dasein, o que, do ponto de vista particular de uma analítica preparatória do Dasein, pode significar um efetivo modo de apropriação das estruturas fundamentais desse ente. Por fim, é a partir do lógos como enunciado que tradicionalmente se desenvolveu o problema da verdade (HEIDEGGER, 2006a, §44). Uma radicalização ontológica da verdade, que será, aliás, um caminho típico da obra heideggeriana, passa também por uma investigação do lógos, ainda que a extrapole.

Ainda no que diz respeito à função e à envergadura do parágrafo na sistemática de Sein und Zeit, poderíamos mencionar que a estrutura do enunciado deverá corresponder, de alguma forma (ainda que como derivação), à estrutura mais ampla da fala (Rede) (HEIDEGGER, 2006a, §34). Com isso, o §33 assume papel central na descrição integral de um lógos fenomenologicamente situado. Mais do que isso: julgamos que importantes momentos da apresentação heideggeriana do enunciado e da fala correspondem a determinadas explicações aristotélicas ${ }^{2}$, às quais nos referiremos. Trata-se aqui, mais uma vez, de um retorno aos gregos contra a dogmática posterior que sobre eles se construiu, mas um retorno que busca destacar sua possível insuficiência ontológica constitutiva.

De início, Heidegger apresenta três aspectos a partir dos quais o enunciado judicativo poderá ser descrito. $\mathrm{O}$ enunciado seria, antes de mais nada, o espaço de uma mostração (Aufzeigung) ${ }^{3}$. Auf-zeigung é, assim, a tradução de Heidegger ao caráter de apó-phansis do lógos predicativo:

1 As citações em alemão serão traduzidas por nós. Quando não for o caso, indicaremos a tradução utilizada.

2 "Nós consideramos o problema do nexo do 'como' com o lógos a partir de uma orientação naquilo que Aristóteles diz sobre o lógos. Pois com ele a meditação antiga atinge seu ápice. Foi ele quem, pela primeira vez, trouxe o problema para uma base adequada e o interpretou de modo tão amplo que nós, se tivermos olhos, poderemos extrair determinadas linhas mestras para nosso problema" (HEIDEGGER, 2010, p. 451).

3 Schuback traduz Aufzeigung por demonstração, opção justificada da seguinte maneira: “a palavra portuguesa demonstração, tomada em sua formação etimológica, corresponde bem aos dois termos alemães Auf-zeigung e Auf-weisung, pois ambos exprimem o movimento de mostrar, indicar, apontar, sem a conotação de seu uso lógico e matemático. Trata-se de uma de-monstração fenomenológica, ou seja, de um mostrar-se por si mesmo e a partir de si mesmo" (HEIDEGGER, 2006b, p. 575). Julgamos, ao contrário, que 'demonstração', para além de sua formação etimológica, carrega primariamente um sentido 'matemático-dedutivo' que não se faz presente nas pretensões heideggerianas. Em todo caso, as duas formas são justificáveis se nos ativermos ao argumento do texto. 
a essência da sentença [Satz] é o apophainesthai - deixar ver um ente, apó-: a partir dele mesmo. O sentido discursivo do enunciado é esse deixar-ver (deloun). O lógos é apophantikós significa que a possibilidade característica dessa fala $[$ Rede] repousa no fazer-ver [...]; ou simplesmente: apóphansis - enunciado: mostração [Aufzeigung] (HEIDEGGER, 1995, p. 133).

De um ponto de vista formal, o enunciado permite que nele se veja o ente assim como o ente mesmo se mostra. Na forma do juízo torna-se manifesto de algum modo o ente, o fenômeno do qual se fala. Mas o lógos só seria capaz de mostrar porque é originalmente lógos tinós: fala é fala sobre (über) e de (von) algo (HEIDEGGER, 1995, p. 142). Assim o autor busca garantir de início um vínculo, uma comunhão intencional entre o fenômeno do enunciado em sua unidade predicativa e o ente que já sempre se manifestou para que um enunciado desse tipo seja possível. Essa tese será desdobrada a seguir.

Mas, na analítica do Dasein, não basta indicar o mero fato de que todo lógos é lógos de algo sem que, paralelamente, se estabeleça o sentido pleno e prévio dessa relação. Ora, sabe-se que a analítica existencial elabora insistentemente os aspectos mesmos desse espaço prévio de manifestação do ente unicamente sobre o qual um enunciado pode ser compreendido como tal e justamente como derivação. O caminho de Sein und Zeit inverte a ordem de acesso ao ente, pois não parte do 'lógico' tradicionalmente compreendido e de suas categorias para chegar a ele, mas prepara, em diversas camadas interpretativas, um campo semântico-hermenêutico prévio de mobilidade e relação ${ }^{4}$. Em todo caso, o aspecto básico que devemos reter agora e a partir do qual o enunciado começa a ser descrito é a mostração mesma, que mantém um vínculo necessário com o ente que já se mostrou a partir (apó-) dele mesmo. Por isso diz o autor:

\begin{abstract}
mesmo quando o ente não está numa proximidade palpável ou 'visível', a mostração visa o próprio ente e não, por exemplo, uma mera representação [Vorstellung] sua, seja ela entendida como 'mero representado', seja como um estado psíquico daquele que enuncia, isto é, seu representar desse ente (HEIDEGGER, 2006a, p. 154).
\end{abstract}

4 Os $\S \S 18,26,29,31$ e 32 de Sein und Zeit são particularmente ricos nesse sentido. 
A pura 'representação psíquica' não deverá servir de base para a descrição fenomenológica destas estruturas existenciais. Para o filósofo, o ser-mostrador do enunciado pressupõe o já ter-se mostrado do ente - do fenômeno - em um mundo, descoberto na significatividade (Bedeutsamkeit) (HEIDEGGER, 2006a, §18) habitual e apropriado hermeneuticamente nas armações circulares do sentido (Sinn) (HEIDEGGER, 2006a, §32). O horizonte mundano é, assim, a medida prévia do mostrar lógico, como dirá Heidegger no seminário de 1929/30 Die Grundbegriffe der Metaphysik5:

[...] para que o lógos [como enunciado] possa satisfazer essa função fundamental da mostração, ele deve ter a possibilidade, para poder ser mostrador, de medir [anmessen] aquilo que mostra ou de tê-lo perdido no mostrar. Pois nele também repousa a possibilidade do poder-ser-falso. O lógos precisa, pois, em si e para si, desse espaço de jogo [Spielraum] do mensurável [Anmessbarkeit] e da inadequação [Unangemessenheit] (HEIDEGGER, 2010, p. 502).

O primeiro aspecto componente do enunciado é, enfim, essa constante referência ao ente que já se abriu de alguma forma (como notamos: na abertura mundana imediata) e que, como dirá o seminário acima, dá e é a medida (Massgabe) para a possibilidade mesma da mostração lógica. Referência ao ente e mostração desse ente são suas marcas mais evidentes.

Mas o enunciado, ao mostrar e para mostrar, já articularia e direcionaria a perspectiva a partir da qual esse ente é mostrado. Por isso Heidegger aponta a predicação (Prädikation) como segunda marca característica do lógos apofântico. Predicação é o nome específico que Heidegger dá à determinação (Bestimmung) que ocorre no enunciado e que atua como o movimento de uma restrição (Einschränkung) (HEIDEGGER, 2006a, p. 155). Ora, determinar, em sentido ontologicamente mais amplo, faz parte de toda articulação projetiva do compreender (Verstehen) do Dasein, resumindo um dos aspectos da mobilidade da existência que se lança no a-cada-vez possível ${ }^{6}$. Assim, este articular do enun-

5 Que já parte de alguns pressupostos diversos daqueles de Sein und Zeit, mas que, em todo caso, compartilha em grande medida de certas descrições frequentes nos seminários dos anos 1920 .

6 Lançado no espaço de um mundo de significações fáticas que não escolheu, o compreender do Dasein, além disso, sempre já se lançou em alguma das possibilidades oferecidas em cada situação e isso não de maneira ocasional ou planejada, mas compreender é apresentado como o 
ciado apofântico, se tomado como modo derivado da articulação ontológica geral, deve atuar, naturalmente, como toda articulação existencial. Os mesmos momentos e estruturas do compreender-interpretativo existencial poderão ser constatados no enunciado, mas agora em uma diversa camada expressiva. A mostração enunciativa seria, portanto, um caso de expressividade (Ausdrücklichkeit), bem como a predicação é um modo de restrição e determinação ${ }^{7}$. Em todo caso, Heidegger descreve do seguinte modo a dinâmica típica do predicar:

os membros da articulação predicativa, sujeito - predicado, crescem no interior da mostração. Não é o determinar que primeiramente descobre, mas ele restringe, como modo da mostração, a visão na direção daquilo que se mostra como tal - o martelo -, para que possa tornar expressamente manifesto o manifesto em sua determinabilidade através da restrição expressa da vista (HEIDEGGER, 2006a, p. 155).

O terceiro e último momento característico do enunciado abre para a investigação do articular existencial um campo que havia sido relegado no §32. O enunciado comportaria em si também: comunicação (Mitteilung), declaração (Heraussage) (HEIDEGGER, 2006a, p. 155). Pois, uma vez que o ser-com pertence à estrutura transcendental do Dasein como ser-no-mundo (cf. HEIDEGGER, 2006a, §26), toda significatividade do ente intramundano deve poder ser articulada e explicada a partir de diversos modos do compartilhamento de seu sentido com o outro Dasein: e não apenas posteriormente, como se a comunicação só fosse possível por uma comparação tardia e mediata dos conteúdos 'expressivos' do enunciado, mas, para que o enunciado possa ser consequentemente explicado como fundado no existir - assim como vinha sendo descrito nos parágrafos anteriores ao $\$ 33$-, já deve pressupor uma partilha de mundo, ou seja, deve pressupor que o mundo, sua medida, seja descoberto significativamente por uma comunidade e que esse ser-comum entre as existências seja uma estrutura apriori do existir em todas suas camadas de articulação:

o ser descobridor pertence ao descerramento [Erschlossenheit] e, assim, ao Da-sein. Na medida em que o

apriori já ter-se lançado (HEIDEGGER, 2006a, §31).

7 Nesse momento Heidegger meramente afirma a similaridade estrutural de ambas articulações, sem descrever ainda o processo que as diferencia e seus domínios próprios. 
Os limites do enunciado apofântico e a posição ontológica da lógica: uma interpretação do §33 de Sein und Zeit
Dndo. Felipe Maia

da Silva [USP]

descerramento pertence dessa maneira ao Da-sein, na medida em que ao descerramento pertence algo compartilhado, e, por isso, tal descerramento comporta indicações do ser-com, ele nunca pode ser demarcado com cercas e barreiras, nunca se mostra como uma propriedade privada, mas é, em si mesmo, ser-com que se descerra, algo sempre já compartilhado por cada Da-sein (HEIDEGGER, 2009, p. 147).

Assim, é a partir da medida proporcionada por um mundo comum (Mitwelt) que os significados crescem para uma comunidade, de modo que fica aberta a possibilidade de que toda sentença mostradora possa ser comprovada pelo outro Dasein em sua 'medida' adequada ao ente a partir da simples verificação do ente sobre o qual se fala ${ }^{8}$.

E, para que o enunciado judicativo atinja a expressividade intermediadora própria da comunicação, Heidegger ainda destaca a declaração (Heraussage) explícita como um momento seu. Comunicar significaria para o Dasein: declarar, pronunciar (aussprechen). Mas, no caso atual do lógos apofântico, o comunicar é um pronunciar exatamente enquanto mostra e predica, como na sentença 'o martelo é pesado', onde se destaca o 'ser pesado' (predicado) do martelo (sujeito) como uma propriedade sua ${ }^{9}$.

O enunciado, em resumo, cumpre a função de tornar o outro atento (mostrar) a um aspecto determinado (predicação) do ente na exata medida em que sobre ele se pronuncia. Nessa comunicação que mostra ao predicar, o ente não necessita estar em uma 'proximidade visível e manejável', isto é, um enunciado pode eventualmente se difundir como tal sem que os 'fios mundanos' da referência primária ao ente sejam acompanhados como tais. Nesse caso, a expressividade do enunciado pode passar a valer por si mesma, como se o próprio enunciado - o dito do dizer, isto é, o legómenon do légein - fosse a fonte primária e o critério de medida a respeito da verdade ou falsidade de um ente. Revela-se aqui, aliás, a dinâmica típica da autenticidade e da inautenticidade da

8 É a partir desse aspecto comunicativo do lógos mostrador que o autor irá desdobrar a temática da verificabilidade universal das ciências e do teor de verdade de suas proposições, que não se fundaria no conteúdo fechado dos juízos e em sua cadeia sistemática como tal, mas precisamente na medida dos significados partilhados que o mundo oferece. (HEIDEGGER, 2009, p. 15-242).

9 Este pronunciar-se categórico do Dasein não mostrará ser, porém, o único modo de declaração comunicativa desse ente. $\mathrm{O} \S 34$ de Sein und Zeit indicará outras possibilidades ('retórica', 'poética') existenciais do aspecto comunicativo do articular. 
Os limites do enunciado apofântico e a posição ontológica da lógica: uma interpretação do §33 de Sein und Zeit
Dndo. Felipe Maia

da Silva [USP]

existência. Também o enunciado mostrador, quando tomado em si mesmo (eu seu ser) como um ente disponível, puramente presente e sem referências (uma declaração simplesmente dada, uma 'verdade corrente'), representaria um caso desse esquema, uma vez que a 'opacidade existencial' dominaria esse discurso. Logo, uma sentença pode ser propagada unicamente 'porque as pessoas dizem assim'. Nesse sentido comenta Heidegger: 'o que se enuncia pode ser 'passado adiante'. O âmbito do que se compartilha conjuntamente numa visão se amplia" (HEIDEGGER, 2006a, p. 155), e nessa amplificação impessoal o discurso mostrador pode revestir-se cada vez mais do caráter de autoridade e 'objetividade', tornando-se dogma ${ }^{10}$.

De um ponto de vista sintético, o filósofo poderá definir então o enunciado como uma "mostração que determina ao comunicar" (mitteilend bestimmende Aufzeigung). Assim, levando em consideração o que havia sido descrito nos parágrafos anteriores de Sein und Zeit no que diz respeito às estruturas pré-apofânticas da existência - assim como ocorrem 'numa primeira aproximação e na maior parte das vezes' -, a mostração tipicamente operada no enunciado, entendida como a descoberta discursiva que aponta para o ente, seria possibilitada unicamente pela abertura prévia ao fenômeno no nível horizontal e interpretativo, ou seja, significativo e semântico e, em todo caso, fático e projetivo. Também a predicação só seria possível como tal porque espelha o determinar, o lançar-se em possibilidades, marca da existência em todos seus níveis expressivos de concreção. A comunicação via enunciado explícito, por fim, não estabeleceria pela primeira vez uma ponte entre o mesmo (Selbst) e o outro (Andere), mas, no novo nexo de fundamentação da analítica, é somente porque o ser-com solícito (Fürsorge) e o ser-junto-a (pre-)ocupado (Besorgen) pertencem à estrutura transcendente do Dasein no nível pré-predicativo que esse ente pode chegar a compreender um juízo geral a partir de seu viés comunicativo - o que já prepara a retirada da linguagem de um plano puramente subjetivista. Nota-se nessa dinâmica argumentativa a redução fenomenológica do ôntico ao

10 No parágrafo em questão o autor não pretende aprofundar, contudo, o estudo forma inautêntica da articulação, mas sobretudo indicar que repousa em sua possibilidade fenomenal própria a queda imersiva no impessoal, caso em que a fala (Rede) se torna pura falação (Gerede). Já no seminário de 1924/25 intitulado Platon: Sophistes, Heidegger distinguia em Platão diversas estruturas do lógos, entre as quais o fato de ele ser tomado como legómenon, e isso no duplo sentido do 1) mero teor (Gehalt) do dito e 2) de sua tendência fática e cotidiana de ser compreendido como mero ter sido dito por alguém, "[...] de tal modo que Aristóteles diz que frequentemente já o ter-sido-dito [Gesagtsein] é suficiente para despertar uma pístis, um convencimento sobre o dito, sem que se tenha apropriado expressamente do conteúdo do dito e do modo do dizer" (HEIDEGGER, 1992, p. 201). 
ontológico (HEIDEGGER, 2005, p. 29). O §33 conclui, portanto, um dos principais esforços de Heidegger ao longo de Sein und Zeit, isto é, indicar que "o enunciado não é um comportamento que paira livre no ar e que poderia, por si mesmo e primariamente, abrir o ente como tal, mas ele já sempre se mantém sobre a base do ser-no-mundo" (HEIDEGGER, 2006a, p. 156).

Modo da interpretação, o enunciado deve consumar analogicamente no nível apofântico as etapas da articulação hermenêutica do compreender fático. O tripé formado por posição prévia, visão prévia e concepção prévia (Vorhabe, Vorsicht e Vorgriff) (HEIDEGGER, 2006a, §32), no qual o articular desdobra a abertura do aí que se move no mundo, já ofereceria à analítica existencial do Dasein um primeiro modelo de constituição do campo significativo e dotado de sentido (HEIDEGGER, 2006a, p. 150-151). Para Heidegger, talvez pudéssemos afirmar, a mostração apofântica não seria suficientemente explicada sem a pressuposição da posição fática e prévia em meio ao ente já aberto pelo compreender-disposto, pois, nesse caso, não se poderia situar a referência do enunciado ao ente a não ser de um modo artificial e posterior (idealmente, como no eu capsular). A apropriação 'perspectiva' do compreendido, conduzida pela visão prévia, seria, por seu turno, o arquétipo da predicação como tal, pois esta, como aquela, atua formalmente no sentido de um destacamento deste ou daquele traço do ente que já se acessou e para cuja perspectiva o Dasein agora se encaminha expressamente. Igualmente, por fim:

ao enunciado como comunicação que determina pertence a cada vez uma articulação significativa daquilo que é mostrado; ele se move em uma determina conceptualidade: o martelo é pesado, ao martelo acrescenta-se o peso, o martelo tem a propriedade [Eigenschaft] do peso. A concepção prévia já sempre presente no enunciar permanece despercebida na maior parte das vezes, porque a linguagem já abriga em si uma conceptualidade elaborada (HEIDEGGER, 2006a, p. 157).

Heidegger parece querer indicar com isso que a lógica, como disciplina filosófica, ao pautar-se quase que exclusivamente em construtos extremos e artificiais de juízos, deles tomando seu ponto de partida, perde, em suas explicações, a base ontológica mundano-existencial (contextualizada) unicamente da qual a linguagem poderia ser tematizada para que sua riqueza semântica prévia possa ser percorrida. O sentido da sentença "o martelo é pesado", caso considerado 
simples e perfeito para o início das análises exclusivamente logicistas, é comumente explicado a partir da pressuposição 'evidente' de que o martelo tem a 'propriedade' (Eigenschaft) do peso. Mas Heidegger indica aqui que não se verifica uma tal enunciação, por exemplo, do ponto de vista circum-mundano primário e imediato da lida prática. O sentido de uma declaração explícita restrita à mobilidade da lida prática poderia ser extraído muito mais das demandas e dificuldades que essa mesma lida oferece $a$ cada vez à interpretação do $D a$ sein na consumação de seus afazeres.

Desse modo, mantendo-se ainda no famoso exemplo do martelo para explicitar sua nova Fundierungszusammenhang, Heidegger indica que não teríamos exatamente, em primeiro lugar, uma abertura do ser do martelo como coisa simplesmente disponível, possuidora de propriedades simplesmente dadas (o peso), que 'valem' independentemente do contexto em que foram expressas. A sentença categórica "o martelo é pesado" deve pressupor, para que seja possível como tal, uma certa rede expressiva e remissiva anterior à forma generalizante, cujo sentido próprio poderia ser melhor identificado nas seguintes declarações: "o martelo é pesado demais", ou simplesmente "muito pesado", "o outro martelo!" (HEIDEGGER, 2006a, p. 157). Com isso apenas se confirmaria, no plano declarativo, o que anteriormente foi analisado, isto é, que o enunciado apofântico logicamente extremo pressupõe diversas relações prévias com o mundo como medida e que esse mundo possui, se assim pudermos dizer, sua significatividade típica e suas construções características de sentido e compreensibilidade. Não se descobre, enfim, primariamente uma propriedade do martelo como tal, mas, por exemplo, a adequação ou inadequação próprias ao seu uso instrumental básico. A esse respeito comenta Nunes:

ao como hermenêutico da visão circunspectiva, articulando, em palavras-frases ("pesado", "este não serve") ou em locuções de ordem ("tragam-me um martelo leve"), de pedido ("deem-me um leve"), de interrogação (“não há um menos pesado?"), de advertência ("pesa demasiado"), a compreensão prévia do martelo, franqueada pelo uso, dentro de um complexo referencial, substitui-se o como apofântico, expresso numa proposição categórica ("o martelo é demasiadamente pesado"), visando propriedades de um ente-à-vista (NUNES, 1992, p. 175) 
Os citados exemplos mundanos e (pre-)ocupados a respeito do peso do martelo como algo que afeta a manutenção da lida prática nem ao menos precisam ser declarados como tais, de modo que mesmo as frases acima já apresentam, segundo Heidegger, uma certa artificialidade que não se encontra usualmente na consumação existencial imediata. A lida prática possui sua própria compreensibilidade (Verständlichkeit) (HEIDEGGER, 2006a, §§14-18, §31) a respeito da adequação ou inadequação do manual que opera, sem precisar proferir uma palavra a respeito disso. Ela já se move na linguagem tácita de sua finalidade relativa (o martelar), já pressupõe que o martelar exige o prego e a tábua e que toda essa rede será mobilizada na direção de uma determinada tarefa (a reforma do telhado, que cobrirá o teto, que protegerá os habitantes da casa da chuva do outono, etc.) e em razão do Dasein mesmo. Toda a rede referencial do instrumento é operada, enfim, por esse jogo articulador-circular de constituição entre todo e parte, se assim pudermos nos expressar: a conjuntura (Bewandtnis) (HEIDEGGER, 2006a, §18).

Do ponto de vista fenomenológico particular da manifestação dos instrumentos, essa conjuntura manual configuraria o espaço totalizante e pressuposto dos significados, sobre cujas possibilidades o Dasein sempre se projeta em uma direção e exatamente pelo intermédio das armações circulares de sentido. Deve-se dizer, inclusive, que quanto mais inaparente e invisível ${ }^{11} \mathrm{o}$ todo-pressuposto das descobertas permanece, mais eficiente são os direcionamentos e mobilizações das partes, o que traduz bem a dinâmica ao mesmo tempo manifestativa e retrativa deste pré-temático.

Mas pode-se objetar que, ainda que se comprove o caráter derivado do enunciado diante de tal 'práxis' em sentido amplo, ainda assim ele faz parte da estrutura natural de concreção expressiva do Dasein e somente a partir dele pode-se erigir, por exemplo, uma ciência universal. Heidegger não nega esse ponto e não parece insistir na formulação de uma nova ordem de fundamentação na intenção de negar a 'validade' da lógica e da ciência, mas a discussão a respeito do enunciado é, antes de mais nada, uma crítica à alegada falta de radicalidade da lógica tradicional, que não seria capaz de descer à base das vivências ontológico-existenciais sobre a qual se funda.

E, considerando exclusivamente os aspectos crítico-destrutivos, nos $\S \S 33-34$ o autor pretende especialmente problematizar o suposto monopólio que a lógica

11 "When we use the doorknob to open the door and get into the next office, we do not attend to its perceptual characteristics. Our attention instead is directed toward where we are going and what we are doing, and the doorknob is used so automatically in familiar surroundings like these that it withdraws from view and serves its instrumental function invisibly. [...] It is this invisible functioning of equipmental things that is definitive of their being in the world of practical activity according to Heidegger (HALL, 1993, p. 126). 
predicativa exerceria sobre a linguagem, abrindo espaço para que se reflita sobre o sentido ontológico-existencial de experiências linguísticas, articuladoras, não restritas à mostração apofântica como tal - ou que delas não partam. Nesse contexto, Nunes indica a importância dessa inversão para a própria filosofia e para as ciências humanas em geral:

essa prévia compreensão [...] reconduz-nos ao círculo hermenêutico ontológico-histórico, que circunscreve, por força da finitude que faz do homem um Dasein, todo trabalho de interpretação, desde a exegese dos textos ao esforço interpretativo da Ontologia Fundamental. Como princípio da exegese textual, o reconhecimento das preconcepções em que o intérprete labora, e que devem ser por ele elaboradas - a sua pertença a um sentido antecipado, que abre o ato mesmo da leitura, a perspectiva temporal que de sua historicidade decorre, a tácita adesão a preconceitos que a tradição lhe impõe -, o reconhecimento dessas pressuposições, que delineiam a compreensão prévia, como mola da interpretação, toca de perto ao problema mais geral do sentido (NUNES, 1992, p. 171-172).

Insistimos que a insuficiência de pressupostos da lógica como preâmbulo das ciências significa, para o filósofo, uma insuficiência onto-lógica fundamental, pois pautar-se unicamente no sentido do que se mostra no juízo como tal significaria, veladamente, absolutizar o sentido do ser como presença e pura posição, com o que se desconsideraria, por exemplo, os aspectos referenciais, contextuais e retrativos da articulação da Erschlossenheit do Dasein em seu horizonte. Também, por seu turno, a típica colocação metafísica do conhecer (erkennen) lógico-teórico como modo de acesso (comportamento) primário ao mundo e correlato da descoberta de puros objetos ideais equivaleria, para Heidegger, a uma renúncia prévia da colocação do problema autêntico da constituição fenomenal própria aos comportamentos imediatos da vida e, portanto, uma renúncia dogmática ao próprio problema da transcendência.

Sendo assim, não se trata, no parágrafo estudado, de uma negação do conhecimento como tal em benefício de algum modo 'primitivo' e natural de sabedoria, como se se propusesse uma valorização do 'irracional' ou ao menos do 'pragmático' contra todo tipo de 'rigor' lógico, mas o novo nexo de funda- 
mentação da analítica do Dasein deve passar necessariamente por uma crítica destrutiva do monopólio lógico sobre o lógos para que, eventualmente, possam ser abertas novas camadas de acesso aos fenômenos articuladores da linguagem existencial. Sabe-se, aliás, que a destruição fenomenológica é parte constituinte do método heideggeriano (HEIDEGGER, 2006a, §6), pois é na história da dogmática metafísica (HEIDEGGER, 2006a, §1) que se esconderiam as mais perigosas naturalizações filosóficas que obstruem o acesso à meditação dos fenômenos. Trata-se aqui, enfim, da intenção de uma ampliação metodológica da filosofia, que não pode se restringir às diretivas e aos resultados lógico-científicos, sejam eles prósperos ou fracassados.

\section{Lógica, metafísica e ontologia}

Uma vez que apontamos rapidamente para o interesse ontológico dessa crítica - ponto ao qual retornaremos - e que se expôs a estrutura típica do enunciado, podemos apresentar os passos através dos quais a analítica do Dasein explica o sentido de sua derivação e modificação em relação à articulação hermenêutica da existência. Trata-se agora, na realidade, de uma indicação geral do sentido de ser deste enunciado e de sua importância para a lógica como disciplina filosófica. Pois, na lógica que se mantém exclusivamente na consideração do enunciado, "o lógos é experienciado como algo presente simplesmente dado [Vorhandenes], é interpretado como tal e, paralelamente, o ente que ele mostra adquire o sentido do ser presente simplesmente dado [Vorhandenheit]" (HEIDEGGER, 2006a, p. 160). Para que o ente que previamente se abriu, numa primeira aproximação, como instrumento-manual seja agora visualizado em sua derivada generalidade de puro objeto contraposto (Gegenstand), faz-se necessário que os caracteres referenciais da manualidade (Zuhandenheit) e da existencialidade desapareçam como tais nesta camada expressiva (ou seja, desapareçam para a visão teórica, permanecendo, contudo, sua condição de possiblidade).

O martelo-instrumento 'com o qual' (Womit) se martelava deve manifestar-se então - na enunciação apofântica - como martelo-coisa 'sobre o qual' (Worüber) se enuncia. Nessa tematização que busca mostrar o ente como pura presença e igualdade, sujeito do enunciado generalizante 'A é B', vela-se necessariamente o nexo mundano e parcial, de modo que o ser-simplesmente-dado passa a ser determinado em seu puro ser-presente-de-tal-e-tal-modo ( $\mathrm{So}$ -und-so-vorhanden-sein): "abre-se agora o acesso a algo como propriedades" (HEIDEGGER, 2006a, p. 158). 
A propriedade passa a valer como o 'que' (Was) simplesmente dado desse ente simplesmente dado, seja 'essencialmente', como uma propriedade eternamente constatável no sujeito-substância-coisa (o triângulo tem três lados), seja 'acidentalmente' (o giz é branco). O próprio verbo intermediário ao sujeito e ao predicado, o "é" paradigmático da lógica, seria visualizado a partir de sua função lógica de cópula. Mas qual a função lógica da cópula? Heidegger responde, baseando-se em uma formulação de Hobbes: "a cópula não é simplesmente a mera ligação [Verbinden], mas ela aponta para o espaço no qual o ser-vinculado se funda. E onde ele se funda? Naquilo que a coisa é, em seu quid (Was), em sua quidditas" (HEIDEGGER, 2010, p. 477). Trata-se aqui, naturalmente, de uma generalização e simplificação das teorias que problematizam a função da cópula no enunciado, mas uma generalização que visa realçar o possível campo comum a partir do qual o "é" é normalmente entendido em tais teorias, isto é, como um vínculo que estabelece o co-pertencimento simplesmente dado entre um sujeito simplesmente dado e uma propriedade simplesmente dada. $\mathrm{O}$ 'é' da cópula instituiria uma relação existencial ${ }^{12}$ entre duas realidades presentes justamente enquanto estabelece o vínculo essencial ou acidental entre essas duas realidades. Por isso completa o autor:

no discurso: essa lousa é negra, não se quer dizer apenas que essa lousa em geral possui essa propriedade como lousa, mas que essa lousa simplesmente dada é simplesmente dada junto [mit] dessa propriedade determinada, de modo que o 'é' também significa ser simplesmente dado. Com o 'é' indica-se aquele ser que investigamos quando perguntamos se $[o b]$ algo é. A essa pergunta, se ele é, respondemos que [dass] ele é ou que ele não é, de modo que também podemos designar esse sentido de ser como Dass-sein [existência] (HEIDEGGER, 2010, p. 481).

O 'é' assume a função de uma colocação vinculativa (cópula) de caráter existencial entre duas existências não somente porque indica como o predicado se inclui no sujeito (se essencialmente ou acidentalmente), mas porque é nele que se decide, paralelamente, se algo é ou não. Em Die Grundprobleme der Phänomenologie, onde Heidegger apresenta o papel do ser na lógica kantiana, podemos ler a respeito desse sentido existencial absoluto do "é":

12 'Existencial' agora no sentido de 'atualidade' ou disponibilidade-presente e não como em Sein und Zeit. 
Os limites do enunciado apofântico e a posição ontológica da lógica: uma interpretação do §33 de Sein und Zeit
Dndo. Felipe Maia da Silva [USP]

vimos que na experiência de existentes repousa também uma síntese, ainda que não a síntese da predicação, ou seja, do acréscimo de um predicado a um sujeito. No enunciado: A é B, B é um predicado real [reales Prädikat] que é adicionado a A. Por outro lado, no discurso: A existe, A é posto absolutamente [absolut gesetzt] e de fato com a totalidade de suas determinações reais B, C, D etc. A A acresce-se essa posição, mas não como no exemplo anterior, onde $\mathrm{B}$ é adicionado a A. Mas o que é essa posição que aqui se acresce? Manifestamente uma relação [Beziehung], mas não uma conexão do algo ou uma conexão real [Sach- und Realverhältnis] no interior do espaço das determinações reais da coisa, do A, mas a referência da plenitude do algo [Sache] (A) ao meu pensamento da coisa [Ding] (HEIDEGGER, 2005, p. 61).

Sem que apresentemos as consequências do diálogo com Kant que a citação pressupõe, podemos dizer que Heidegger pretende realçar aqui o fato de que no enunciado o 'é' é interpretado como cópula; mas a cópula mostra exemplar e definitivamente seu sentido existencial de Wirklichkeit, atualidade enquanto posição absoluta do ente em sua presença, na forma de um enunciado positivo simples do tipo: Deus é. Ficam indicados assim, em todo caso, os modos ontológicos básicos levantados nos enunciados lógicos categóricos (seja na forma relacional 'A é B', seja na forma absoluta 'A é') a partir da análise de seus três elementos típicos - sujeito, predicado e cópula. $\mathrm{O}$ enunciado apofântico (logicamente e metafisicamente compreendido), portanto, tenderia a mostrar o que é (essencial ou acidentalmente: Was-sein-So-und-so-sein) o ente sobre o qual se fala na predicação, ao mesmo tempo em que é capaz de estruturar a posição ou não posição (existência: Dass-sein) desse ente, tendo, contudo, já pressuposto o sentido de ser de seus termos como seres presentes e disponíveis.

Logo, os termos da relação apofântica, assim como a própria relação, assumem na lógica uma função ontológica determinada, onde a Vorhandenheit é paradigmática, sendo a própria negação tomada como mera ausência de positividade. Estariam dados os pressupostos para a construção de um saber positivo que ultrapassa a finitude e limitação constitutivas de cada Dasein, mas que só o faz na exata medida em que abandona o fundamento mundano e contextual do qual partiu e que, ao abandoná-lo, é capaz mesmo de esquecê-lo e suprimi-lo. 
Poderíamos afirmar que nessa estruturação lógico-metafísica dos componentes do lógos e do ponto de vista ontológico estruturado na primeira parte de Sein und Zeit a partir da analítica do Dasein, a consumação circular e medial do possivel e fático nos jogos entre parte e todo, manifestação e retração, perde espaço frente à força do positivo e da tendência lógico-metafísica ao estabelecimento de fundamentos e princípios seguros. Tendo em vista essa colocação metafísica do problema, Heidegger pode concluir no seminário de Freiburg de 1928-29 intitulado Einleitung in die Philosophie:

durante muito tempo a metafísica viu-se ensandecida pelo positivo que, em razão de sua aparente primazia sobre o negativo, se arroga ser o absoluto e originário. Foi de acordo com esse pressuposto que se construíram a nossa lógica tradicional, a nossa ontologia e a nossa doutrina das categorias. Seus conceitos não nos levam longe o suficiente para que possamos alcançar o que se tem em vista com o termo 'nulidade' (HEIDEGGER, 2009, p. 355).

Ora, retomando ao $\$ 33$ de Sein und Zeit, é na sistemática do enunciado apofântico, centro da lógica, que se abre a possibilidade para que o ente se mostre a partir das marcas acima indicadas, pois, segundo o autor, na apóphansis

a estrutura-como da interpretação sofreu uma modificação. O 'como' já não recorre, em sua função de apropriação do compreendido, ao espaço de uma totalidade conjuntural. Ele separou-se, no que diz respeito a suas possibilidades de articulação das relações referenciais, da significatividade constitutiva da circum-mundanidade. O 'como' é reprimido no plano uniforme daquilo que é simplesmente dado na presença. Afunda-se na estrutura do apenas-deixar-ver determinante do simplesmente dado. Esse nivelamento do 'como' originário da interpretação circum-visiva na direção do como da determinação do ser simplesmente dado constitui a distinção do enunciado (HEIDEGGER, 2006a, p. 158). 
A crítica heideggeriana à lógica inverte-se paulatinamente, assim, em crítica à metafísica, uma vez que não mais se percebe os limites que separam as duas disciplinas. Seu ponto comum é, contudo, a insuficiente pressuposição ontológica fundamental do ser como presença, ou seja, do ser como Vorhandenheit, disponibilidade, contra-posição.

E, analogicamente, se se estabelece a entidade do ente, o ser do ente, nas diversas formas de presença (nas ideias e na ideia suprema, na forma como atualidade, em Deus como ato puro), também o comportamento descobridor, a 'razão' e o 'discurso' humanos - a imbricação entre ratio e lógos, pensamento e linguagem - será tanto mais concordante com esta verdade ôntica quanto mais a ela se aparentar, ou seja, quanto mais for presença. Por isso diz Heidegger no seminário de inverno de 1925/26:

um comportamento [Verhalten] como comportamento é presente, na medida em que tem o sentido do presentar [Präsentieren], ou, como se diz em alemão: do apresentar de algo [Gegenwärtigens von etwas]. Como esse apresentar, o comportamento permite que algo presente [Anwesendes] se dê ao encontro. Ao apresentar, ao presentar de algo corresponde a presença [Anwesenheit] daquilo que satisfaz a apresentação, que nela subjaz e que no apresentar mesmo é descoberto e aberto (HEIDEGGER, 1995, p. 192).

É, logo, no enunciar teórico-mostrador do Dasein como comportamento possível desse ente que a metafísica encontraria o comportamento paradigmático para sua concepção ontológica de base: o juízo passa a ser, para a tradição filosófica, o lugar unicamente a partir do qual a verdade deverá ser buscada ${ }^{13}$. A lógica assim restrita, diz o autor, será então a base propriamente dita da metafísica, com o que completa:

o mais agudo indício disso encontra-se no fato de que atualmente nós, sem jamais retornar à origem, de modo abrupto e impensado, designamos aqueles elementos do ser, os quais reconhecemos como os autênticos, tor-

13 Tema do $\$ 44$ de Sein und Zeit e que devemos abordar a seguir, de um modo insuficiente, contudo, uma vez que se abre nesse ponto um campo considerável de problemas que extrapolam os limites deste artigo. 
nando-os o problema da metafísica, como categorias. Kategoría significa em grego: enunciado [Aussage]. [...] Este fenômeno do lógos não é somente reconhecido na filosofia como tal, especialmente na lógica, mas o lógos no sentido amplo de razão [Vernunft], ratio, é a dimensão a partir da qual a problemática do ser será desdobrada, fazendo com que Hegel, o último grande metafísico da metafísica ocidental, faça coincidir a metafísica com a lógica enquanto ciência da razão (HEIDEGGER, 2010, p. 419-20).

Completa-se desse modo um importante circuito interno da Ontologia Fundamental de Sein und Zeit, que sabidamente parte da tarefa de uma (re-)colocação do problema do sentido do ser, buscando na analítica do Dasein como ser-no-mundo cotidiano seu fio condutor imediato (o fio condutor apropriado para a extração das estruturas existenciais desse ente) para que, nos capítulos culminantes da primeira parte da obra, o caráter existencial derivado da postura teórica e do enunciado judicativo possa ser reconduzido ao centro do problema histórico-ontológico. O predomínio da lógica na metafísica (ou, inversamente, o domínio metafísico sobre a lógica) passa a significar uma limitação ontológica fundamental e, de acordo com a tendência fenomenológica operante na analítica do Dasein, somente o retorno da atenção ao articular hermenêutico-circular constitutivo da abertura existencial poderá satisfazer as exigências ontológicas diversas desse exato campo prévio, preparando as estruturas que serão profundamente interpretadas na segunda metade da obra em questão.

O que tradicionalmente se entende por essência e existência, os espaços onde se decide o ser dos entes, passa, nesse grande projeto filosófico de Heidegger, pelo filtro da crítica à ontologia da presença e tudo que a ela diz respeito. Diante dela e contra ela o autor realça insistentemente o predomínio do possível sobre o atual, do finito e relacional (a situação hermenêutica) sobre o infinito e a-relacional, dos aspectos ôntico-ontológicos tanto retrativos quanto positivos sobre a pura posição absoluta, do prático em sentido amplo sobre o puramente teórico. Assim, de certa forma, as partes publicadas de Sein und Zeit já preparam veladamente a possibilidade da inversão do pensamento, pois qualquer tomada de caminho na colocação do problema do ser pressupõe a dinâmica circular e finita de seu acontecimento. A esse respeito comenta Stein: 
enquanto a fenomenologia é utilizada para a analítica da facticidade e da existência, ela se torna hermenêutica; passa a se movimentar num círculo hermenêutico. Essa circularidade, que não é apenas característica da compreensão, mas através dela, do próprio ser-aí, também apresenta uma ambiguidade que acompanha toda a obra de Heidegger. Pelo método fenomenológico se desvendou esta circularidade, que passa, por sua vez, a possibilitar uma verdadeira penetração na fenomenologia. A estrutura circular da interrogação heideggeriana leva-o ao que se chamará viravolta (Kehre). [...] A Kehre é um movimento pelo qual o filósofo, uma vez realizada a mediação pela analítica, se volta para o ser e a partir dele analisa o homem (STEIN, 1983, p. 119-20).

Preparatória de um caminho e consciente disso, a analítica deve deixar muitas indicações provisórias e lacunares. A rigidez da contraposição entre um enunciado teórico extremo do tipo 'A é B' e a descoberta da significatividade mundana mais elementar, prescinde, por exemplo, da descrição fenomenológica integral exigida por outros momentos expressivos intermediários (Zwischenstufen) do articular: "enunciados sobre acontecimentos no mundo-circundante, relatos de manuais, "relatórios de situação", apreensão e fixação de uma 'ocorrência', descrição de um estado de coisas, narração do que se passou" (HEIDEGGER, 2006a, p. 158). Em todo caso, Sein und Zeit também prepara o espaço fenomenológico de consideração de outras formas do lógos, negligenciadas pela tradição, pois nelas aparentemente não se cumpriria exemplarmente o sentido da presentificação do ente verificado na enunciação predicativa simples.

O mundo, enquanto espaço horizontal do jogo entre facticidade e projeção, recepção de signos constituídos e constituição de signos, enfim, enquanto espaço da concreção do ser-possível, equivale agora à medida, à régua da transcendência - e entendemos que somente sob esse ponto de vista o $\$ 33$ deixa-se explicar. É nesse deixar-se vincular (Sichbindenlassen) (HEIDEGGER, 2010, p. 497) circular do Dasein transcendente ao mundo, mencionado no começo deste trabalho a partir da referência ao seminário Die Grundbegriffe der Metaphysik, que ocorreria, inclusive, o acontecimento onto-lógico da fundamentação como princípio - e não nas leis da lógica tomadas 'em si mesmas'. A liberdade lógica da interpelação, da apóphansis, que se move no espaço mostrador, determinador e comunicativo dos conceitos, parece ser, assim, fundada na liberdade pré- 
Os limites do enunciado apofântico e a posição ontológica da lógica: uma interpretação do §33 de Sein und Zeit
Dndo. Felipe Maia

da Silva [USP]

via da transcendência, e esta, por sua vez, unicamente enquanto um ontológico deixar-se vincular do Dasein à medida mundana do ente, do fenômeno ${ }^{14}$.

Nesse sentido, e de acordo a metafísica, o princípio lógico da razão suficiente (nada existe sem razão - tudo tem uma razão) deve poder explicar o fundamento ontológico do homem, e isso na exata medida em que, concordante com seu viés típico, insistentemente o encaminha para um fundamento presente, certo e estável: um substrato como o Deus-motor de viés aristotélico, a ideia divina do bem, o Cogito cartesiano também remetido a Deus, etc. Nunes, tendo em vista o famoso Vom Wesen des Grundes de 1929, comenta:

mas o que é, afinal, esse princípio, como arché? [...] Para Leibniz, trata-se da causalidade, que se firma na existência de uma primeira causa, interpretada como ser necessário e fim de tudo o que existe, também razão do conjunto das coisas, o porquê da ordem espiritual e natural. Do ponto de vista da Ontologia Fundamental, que reduz o conhecimento ontológico à condição temporal de sua possibilidade, a essência do fundamento revela-se nesse porquê, possibilitado pela transcendência, que deixa o Dasein livre para instaurar a ratio - para dar razão, rationem reddere, para fundamentar (begründen) -, na medida em que, como projetante, já se encontra em meio à totalidade do ente (NUNES, 1992, p. 183).

Uma vez que Heidegger põe na liberdade (sobretudo a partir do final dos anos 1920) o princípio do Dasein, e que essa liberdade só permanece livre na possibilidade articulada de um deixar-se vincular prévio pelo mundo - quando se lança em fundações e projetos em meio ao ente -, toda instauração da ratio, todo lógos apofântico, deverá ser direcionada necessariamente a essa medida mundana aberta e livre ${ }^{15}$. Ao mesmo tempo, poderíamos talvez nos perguntar

14 Este modo de apresentação do problema da liberdade e do vínculo mundano, longe de restringir-se ao Walten der Welt dos textos posteriores a Sein und Zeit, já se encontra presente, a nosso ver, nas diversas descrições circulares das constituições fenomenais na obra de 1927 e exatamente no teor de termos ali recorrentes como Freigabe e frei lassen, Bewandtnis e Bewendenlassen, begegnen lassen, etc.

15 A esse respeito diz F. Volpi: “es evidente que, em consonância com lá evolución de su postura especulativa, Heidegger modifica su modo de comprender el fundamento ontológico del lógos, subrayando precisamente en la cooriginariedade del plexo ser-ahí y mundo, aperturidad y ser-abriente, ya no la configuración activa de la apertura de parte del ser-ahí, sino más bien su estar situado em um acontecer que la engloba y comprende. Esto prefigura con claridad los resultados a los que llega, por ejemplo, em el curso del semestre de verano de 1935, em 
Os limites do enunciado apofântico e a posição ontológica da lógica: uma interpretação do §33 de Sein und Zeit
Dndo. Felipe Maia

da Silva [USP]

se o próprio movimento desta liberdade que se deixa vincular nas camadas ontologicamente mais primárias do acontecimento do mundo e da transcendência não se deixaria explicar como o acontecimento de uma articulação, com o que se ampliaria radicalmente a noção deste $\operatorname{ló} g o s^{16}$.

Em todo caso, concluímos esta seção ao afirmar, na esteira de Heidegger, que a lógica, 'metafisicamente' considerada, quando pretende remeter o ente humano, em sua racionalidade e linguagem, a um fundamento simples e unívoco, já passou ao largo do sentido abismal (ab-gründig) livre, possível e circular de sua transcendência articuladora, de seu lógos existencial, tornando-o auto-referente e, em certa medida, absoluto. Esse pano de fundo ontológico, que, com algumas modificações importantes, continuará a ser paradigmático para o pensamento heideggeriano dos anos 1930, já se apresentava esboçado, logo, em Sein und Zeit e em textos contemporâneos.

\section{A presença aristotélica}

O §33 de Sein und Zeit apresenta, em suma, uma decisiva indicação da derivação da estrutura-como apofântica em relação à estrutura-como hermenêutica - e isso na exata medida em que a analítica já se baseia em uma fenomenologia prévia do Dasein como ser-no-mundo. Em complemento a essa tarefa, algumas breves informações condensadas no fim do $\S 33{ }^{17}$ parecem indicar, contudo, que a alegada visão dogmática da lógica tradicional a respeito do papel dominante e quase monolítico do enunciado categórico não corresponderia exatamente ao sentido das reflexões daquele que é considerado o primeiro grande lógico sistemático, isto é, Aristóteles. Para Heidegger, Aristóteles teria considerado o lógos a partir de uma perspectiva mais radical e ampla do que as 'superficiais teorias do juízo’ posteriores, que seriam, na verdade, simplificações daquilo que, para

la Introducción a la metafísica, em la cual, intentando esclarecer la dimensión premetafísica del pensamento, Heidegger retoma su teoria del lógos y la reformula proponiendo substituir la definición del hombre como zôon logon ekhôn por uma comprensión de la Physis como lógos ánthropon ekhôn" (VOLPI, 2012,p. 164.)

16 Como vaga hipótese e horizonte de pesquisa, perguntamo-nos: o que é a temporalidade, analisada na segunda metade de Sein und Zeit, senão uma nova indicação formal para o acontecimento do articular? Como se constituirá a meditação sobre a verdade senão a partir do jogo articulador do ser? A phýsis, a história da metafísica, a obra de arte, não seriam paragens onde se manifesta o articular como Streit, luta, e onde se desdobra, em conclusão, o acontecimento da diferença entre ser e ente?

17 Amplamente estudadas em seminários dos anos 1920 a partir das mais diversas aproximações. Naturalmente não poderíamos desenvolver nesse espaço a totalidade das interpretações heideggerianas de Aristóteles, mas algumas indicações particulares serão úteis. 
o grego, era uma questão viva. A partir de determinados aspectos do diálogo de Heidegger com Aristóteles, que esboçaremos a seguir, poderemos notar a proximidade entre as duas teorias, mas também o limite que as separa. Os temas aristotélicos poderão auxiliar, enfim, no esforço de interpretação integral do $§ 33$.

Heidegger menciona que o Estagirita teria destacado o fato de que "todo enunciado [apophansis], quer afirmativo ou negativo, verdadeiro ou falso, é de maneira co-originária sýnthesis e diairesis" (HEIDEGGER, 2006a, p. 159). Mais do que isso: para que o lógos apofântico mesmo cumpra suas articulações mostradoras próprias na afirmação (katá-phasis) e na negação (apó-phasis) e para que nele seja possível a verificação de algo como falso ou verdadeiro, deve estar fundado, de algum modo, na dinâmica articuladora prévia verificada no jogo mútuo da synthesis e da diairesis, termos para os quais Heidegger oferece diversas traduções, sendo os mais frequentes Verbinden (junção) e Trennen (separação), respectivamente. Em Sein und Zeit, porém, o autor não aprofunda especialmente essa reflexão, mas os seminários nos oferecem importantes orientações.

Se, assim, o lógos, em sua operação, se fundaria em um articular que, ao mesmo tempo, separa e junta, Heidegger, em Die Grundbegriffe der Metaphysik ${ }^{18}$, aponta para o fato de que a função do lógos em geral (e não apenas do lógos apofântico) é especialmente descrita na famosa passagem do De interpretatione: "èsti dè lógos hápas mén semantikós...", assim traduzida livremente pelo filósofo alemão: "cada fala [Rede], toda fala, possui em si a possibilidade de dar algo a entender [etwas zu bedeuten zu geben]; aquilo que nós compreendemos" (ARISTÓTELES, 1844, 4, 17 a 1 apud HEIDEGGER, 2010, p. 443). Típico do lógos, e essa lição Heidegger extrai explicitamente de Aristóteles, seria sua função semântica, pois nele um significado é propagado e pode ser compreendido. Mas esse dar a entender significativo de todo lógos acontece “...oukh hos òrganón dé, all'ósper eiretai, katà synthéken: [...] não como um funcionar [Funktionieren], como conhecemos no caso dos órgãos" (ARISTÓTELES, 1844, 4, 17 a1 apud HEIDEGGER, 2010, p. 444), não como o decurso de processos físicos naturais como a circulação do sangue ou a digestão, mas 'katá synthéken' - de acordo com uma convenção (Übereinkunft).

Heidegger prossegue sua exposição do De interpretatione e busca indicar o sentido da afirmação anterior, segundo a qual o dar a entender significativo de todo lógos é explicado como uma convenção que ultrapassava o mero 'físico'. Puramente 'natural' seriam os psóphoi, os barulhos e sons emitidos pelos animais, aos quais faltaria um significado. O ser-convencional do lógos humano

18 E também em Logik. Die Frage nach der Wahrheit, de modo extensivo. 
se dá, por outro lado, "ótan génetai sýmbolon, [...] sempre que acontece um símbolo" (ARISTÓTELES, 1844, 2, 16 a 7 apud HEIDEGGER, 2010, p. 444). Nesse ponto Heidegger aproxima-se de Aristóteles, pois pretende mostrar que o grego não define a fala humana simplesmente pelo som (phoné) que é emitido - e que de fato acompanha todo dizer -, mas justamente por uma convenção significativa que acontece sempre quando um 'símbolo' ocorre. O que é, então, o acontecimento de um símbolo? Heidegger responde da seguinte maneira:

devemos tomar cuidado ao traduzir sýmbolon por símbolo, utilizando um sentido de símbolo atualmente corrente no lugar de sýmbolon. Symbolé significa o lançar conjunto de um para outro [Zusammenwurf des einen mit dem anderen], o manter em conjunto de algo com um outro [Zusammenhalten von etwas mit einem anderen], ou seja, manter um no outro [Aneinanderhalten], conformar ao outro e no outro [An- und Ineinanderfügen]. Por isso sýmbolon significa algo como conformidade [Fuge], costura [Naht], a articulação [das Gelenk], que não apenas traz um para o lado do outro, mas que os mantém em um conjunto, de modo que se ajustem mutuamente (HEIDEGGER, 2010, p. 445).

Interpretando Aristóteles, Heidegger extrai o pensamento de que a condição de possibilidade da fala humana em geral como um dar a entender significativo é a convenção, que pode ser lida no acontecimento do símbolo. Mas o símbolo seria esse ajuste, essa conformidade do homem com algo, sem cuja articulação prévia nem mesmo o dar a entender de algo como algo seria possível. Isso só é possível, diz Heidegger, extrapolando o pensamento grego, porque o homem já acontece, segundo notamos acima, como um ente que se consuma no aí, na dimensão prévia onde toma medida junto ao ente que se manifesta e na direção de si mesmo e do outro. Nesse sentido, cada palavra só acontece como tal (na escrita, na conversa, na escuta, etc.) porque pressupõe um campo semântico-mundano já aberto. Desse modo, Heidegger apropria-se de Aristóteles na intenção de indicar que também o grego não teria estabelecido o pensamento sobre o lógos já na própria lógica fechada em si mesma e com pura análise dos juízos. De alguma forma, segundo Heidegger, Aristóteles (e os gregos de forma geral) ainda mantinha-se na relação da palavra com o ente, sendo o ente o permanente critério da convenção, do símbolo, entendido como articulação prévia. 
Os limites do enunciado apofântico e a posição ontológica da lógica: uma interpretação do §33 de Sein und Zeit
Dndo. Felipe Maia

da Silva [USP]

Por isso o pensador alemão resume suas intenções na seguinte passagem: "só acontece linguagem em um ente que, de acordo com seu essenciar, transcende" (HEIDEGGER, 2010, p. 447).

Na continuação da primeira passagem citada do De interpretatione, Aristóteles efetua claramente uma distinção entre o que pertence a todo lógos - ou seja, o dar a entender significativo e convencional -, e o que é típico unicamente do lógos apophantikós, da fala mostradora do enunciado teórico, da Aussa$g e^{19}$. Dessa forma, o filósofo poderia dizer que todo lógos é phoné semantiké, um som significativo, mas nem toda fala tem a função do mostrar determinador categórico. Tão importante quanto isso: somente no enunciado mostrador decide-se algo sobre o ser-verdadeiro (aletheúein) ou o ser-falso (pseúdesthai) de algo. Assim, em contraste, a compreensão natural de um pedido, ordem ou pergunta, segundo a interpretação heideggeriana de Aristóteles, não se concentraria tanto sobre sua verdade ou falsidade, ou seja, sobre o conteúdo mostrador ou encobridor desses modos de discurso ${ }^{20}$ - e também sobre esse ponto estrutura-se a diferença específica entre essas outras formas de lógos e o lógos mostrador do enunciado.

Na pesquisa aristotélica, a retórica e a poética, por exemplo, seriam ciências mais apropriadas para tratar do conteúdo dessas formas não-teóricas do lógos. Heidegger parece indicar com isso que, ao colocar a decisão sobre a verdade e a falsidade dos entes unicamente (ou melhor: predominantemente) na análise dos discursos mostradores, Aristóteles teria praticamente obstruído a reflexão filosófica a respeito da radicalidade de fenômenos e comportamentos não-teóricos, ainda que, curiosamente, ele mesmo tenha reconhecido que a práxis e a poíesis são, de fato, âmbitos de comportamento articulados por suas respectivas razoabilidades descobridoras significativas (cf. HEIDEGGER, 1992, p. 1-188). Sabe-se, nesse sentido, que a Ética a Nicômaco $^{21}$ estabelecia diversos graus de 'dignidade' dos comportamentos dianoéticos - medidos justamente por suas

19 "[...] apophantikós dè ou pas" (ARISTÓTELES, 1844, 4, 17 a 2 apud HEIDEGGER, 2010, p. 448).

20 No seminário de 1925/26 (HEIDEGGER, 1995, p. 130), o autor nota que esse é um problema vivo e já Bolzano, além de Husserl, teria indicado um determinado caráter 'enunciativo' ou mostrador no caso de discursos de pedido, ordem e pergunta. Por ora, para aquém desta controvérsia, Heidegger pretende apenas estruturar a resposta aristotélica do problema da diferenciação entre as 'espécies de lógos'.

21 Sobretudo o livro VI, extensamente estudada por Heidegger nos anos 1920. Como nota Volpi, a leitura de Aristóteles permitiu que o filósofo alemão entendesse que "[...] a teoria é apenas uma das muitas maneiras de comportamento descobridor, através do qual o Dasein obtém acesso ao mundo e o apreende. Ao lado da teoria e mesmo antes dela encontram-se a Praxis e a Poiesis, que de igual maneira constituem modos do comportar-se descobridor do homem para com o ente" (VOLPI, 2007, p. 169). 
possibilidades e capacidades enquanto comportamentos descobridores: a contemplação teórica da filosofia, verdadeira sabedoria (sophía), ocupando o posto privilegiado de modo excelente de vida, uma vez que é no discurso teórico da filosofia que se pode investigar os princípios supremos e necessários, sempre iguais a si mesmos e condizentes com o sentido grego de verdade.

Com isso, contudo, já intuímos os motivos ontológicos dos privilégios ofertados ao lógos apofântico e à teoria. Esse lógos seria aquele “...en hói tò aletheúein è pseúdesthai hypárkhei: [...] no qual o descobrir ou o encobrir suporta e determina a própria intenção da fala" (ARISTÓTELES, 1884, 4, 17 a 1-3 apud HEIDEGGER, 1995, p. 129). Ora, Heidegger traduz a verdade como um descobrir, enquanto a falsidade é entendida como um encobrir. Nesse sentido, de acordo com a tradição, o juízo afirmativo (katáphasis) pode descobrir um ente assim como ele é, caso em que normalmente se diz que ele é verdadeiro (a lousa é negra), ou descobridor. A verdade da operação afirmativa concentra-se nesse mostrar predicativo de algo como algo que, de algum modo, se comprova como tal a partir da própria coisa. Daí o tradicional conceito da verdade judicativa como uma adaequatio rei et intellectus. Mas também uma proposição articuladora negativa pode ser verdadeira/descobridora, como quando se diz: a lousa não é amarela. Da mesma forma, pode-se concluir que tanto uma afirmação pode ser falsa/encobridora (a lousa é amarela) como também uma negação (a lousa não é negra).

Ora, na definição heideggeriana do lógos apofântico, o autor estabelecia, como vimos, a necessidade de uma referência prévia do enunciado ao ente que já se abriu - na exata medida em que mostra esse ente como o ente que se abriu como tal. Mas, de acordo com o autor, "o lógos mostrador, também quando encobre, deve ainda ser mostrador. Para que eu possa julgar falsamente, para que possa enganar, devo, enquanto falo, viver em uma tendência falante que intenciona mostrar algo. Também o encobrir se funda em uma tendência mostradora" (HEIDEGGER, 2010, p. 452). Com isso, Heidegger certamente não contesta o caráter descobridor e encobridor (falsificador) do enunciado; comentamos que o filósofo basicamente pretende mostrar, em sua crítica à lógica tradicional e ao posicionamento tradicional da verdade no juízo, que, para que a adequação ou inadequação do enunciado à coisa seja possível como tal, o Dasein já deve ter aberto o mundo e estar nele imerso. Ou seja, o 'lugar' da verdade é remetido para um campo anterior àquele relativo ao lógos apofântico, embora também ele efetue, a seu modo, os 'desempenhos do descobrir'.

Mas se se trata, nesse caso, de uma leitura de Aristóteles, e se, de acordo com a 
explícita interpretação heideggeriana, Aristóteles teria estabelecido o fundamento de todo lógos numa certa conveniência semântica, que se dá exatamente como acontecimento de um símbolo enquanto a conformidade prévia de algo com algo, então poderíamos deduzir que, também para o aluno de Platão, o lógos apofântico apenas articula, a seu modo (como afirmação e negação), uma adequação prévia do homem, isto é, um acontecimento anterior de conformidade.

Heidegger formula do seguinte modo a questão decisiva decorrente dessa argumentação: "onde se funda a possibilidade seja do descobrir, seja do encobrir? Como o lógos deve ser em si, de acordo com sua mais íntima estrutura essencial, para que nele descobrir ou encobrir sejam possíveis?" (HEIDEGGER, 2010, p. 453-54). Recorrendo ao terceiro livro do De anima, onde o filósofo grego estuda o homem enquanto vivente e o lógos justamente como o caracteristicamente humano em relação aos animais e às plantas, Heidegger encontra uma indicação da condição de possibilidade do lógos humano ser descobridor ou encobridor: "en hóis dè kaì tò pseúdos kaì tò alethés, sýnthésis tis ède noemáton hósper hén ònton", cuja tradução heideggeriana soa: "no âmbito daquele espaço, em relação ao qual tanto o encobridor quanto o descobridor são possíveis, ali já ocorre algo como uma junção [Zusammensetzung] (um tomar em conjunto) do percebido [Vernommenen], de tal modo que o percebido, por assim dizer, forma uma unidade" (ARISTÓTELES, 1911, 6, 430 a 27 apud HEIDEGGER, 2010, p. 454).

Com isso completamos um ciclo e voltamos à questão exatamente como ela se apresentava, extremamente resumida, no $\$ 33$ de Sein und Zeit. Para que o lógos apofântico seja possível como tal em sua função descobridora e encobridora, em sua verdade e falsidade, em sua operação afirmativa e negativa, já deve ter ocorrido uma certa síntese, uma junção do percebido (noemáton) - e uma junção que atue precisamente na operação formativa de unidade (hósper hén) do percebido. Na interpretação de Heidegger, logo, o percebido como tal, possibilitador do lógos, deve ser aberto como unidade, pois é próprio do caráter de percepção do percebido a síntese, a junção do percebido como unidade. Mas a faculdade de percepção do percebido é a nóesis, o nóus: um perceber de... (Vernehmen von...) como junção e unidade, como fica indicado no seminário de 1929/30 (HEIDEGGER, 2010, p. 452-456). Tal síntese do percebido deve configurar, portanto, de alguma forma, o caráter de descoberta que precede a descoberta típica da apóphansis - e nesse ato sintético aconteceria propriamente o sýmbolon, como a manutenção de uma conformidade semântica conven- 
cional, com o que encerramos um pequeno e emaranhado circuito interno, mais indicado nas entrelinhas de Sein und Zeit do que propriamente explorado, e que busca indicar a possibilidade de se ler em Aristóteles a essência de todos lógos, de seu 'ser-semântico', a partir de sua relação com o conceito de noein e, mais do que isso, como uma conveniência estruturante prévia entre articulação dos sentidos e mundo, anterior à conceptualidade apofântica.

E, ainda que se possa discutir a validade e a amplitude das similaridades entre as marcas do nóus aristotélico e da abertura (Erschlossenheit) horizontal prévia do Dasein na disposição e no compreender interpretativo, pretendemos aqui apenas indicar um aspecto decisivo da exposição heideggeriana: o fato de que o autor busca problematizar e radicalizar a recepção tradicional - dogmática - da obra de Aristóteles no que diz respeito ao lógos. Não se trata tanto, além disso, de demonstrar que a abertura do Dasein e o nóus aristotélico sejam idênticos ou muito menos de empreender, por outro lado, uma análise filológica completa da 'epistemologia' grega. A nosso ver, o autor pretende muito mais abalar e contestar o viés ontológico concentrado no interesse da lógica pela apóphansis na medida em que aponta para seu possível caráter derivado em relação à percepção e aos sentidos - e isso exatamente no primeiro grande lógico da metafísica, naquele ao qual tradicionalmente se recorre quando se quer estabelecer o enunciado judicativo como lugar primário e excelente da verdade ${ }^{22}$.

Fato é que, além de apontar ali para a possível dependência e derivação da apóphansis a um contato antecipado e originário do homem com o ente mundano através da percepção - com o que o filósofo alemão já teria trazido Aristóteles 'para seu lado', ou seja, para o lado de uma fenomenologia que situa o pré-predicativo no âmbito das estruturas do ser-no-mundo, da Sorge como estrutura integral do existir -, Heidegger parece mesmo retirar de certas indicações aristotélicas sobre a dinâmica da percepção certos traços de seu próprio conceito de articulação, o que exprime reiteradas vezes em seminários, como na seguinte passagem:

22 O $\$ 44$ de Sein und Zeit retoma essa tarefa, como podemos extrair dessas passagens conclusivas: "Aristóteles jamais defendeu a tese de que o 'lugar' originário da verdade fosse o juízo. Ele diz muito mais que o lógos é o modo de ser do Dasein que pode ser descobridor ou encobridor. Essa dupla possibilidade é o distintivo do ser-verdadeiro do lógos, pois ele é um comportamento que também pode encobrir. [...] E somente porque a nóesis descobre primariamente é que também o lógos enquanto dianoeín pode ter a função de descoberta" (HEIDEGGER, 2006a, p. 226). 
Os limites do enunciado apofântico e a posição ontológica da lógica: uma interpretação do §33 de Sein und Zeit
Dndo. Felipe Maia

da Silva [USP]

quando Aristóteles fala da sýnthesis nesse contexto, então ele se refere àquilo que nós denominamos estrutura-'como'. Ele quer dizer isso sem, no entanto, penetrar expressamente na dimensão desse problema. A estrutura-'como', a prévia percepção formadora de unidade de algo como algo, é a condição de possibilidade da verdade e da falsidade do lógos. Devo já ter mantido numa visão a lousa negra como algo unitário para destrinchar o percebido no juízo (HEIDEGGER, 2010, p. 456).

Para que a apropriação heideggeriana de Aristóteles seja bem compreendida em seus pressupostos ontológicos e para que daí possamos retornar à fenomenologia do ser-no-mundo, uma outra passagem do De anima é rapidamente levantada para completar o sentido pleno da operação do perceber: "endékhetai dè kaì diaíresin phánai pánta: pode-se também denominar ou tomar como diaíresis, separação [Auseinandernehmen], tudo que mostrei sob o nome de sýnthesis" (ARISTÓTELES, 1911, 6, 430 b 3f apud HEIDEGGER, 2010, p. 457). A meta dessa passagem seria resumida, por fim, na intrigante passagem do De interpretatione, segundo a qual: "perí gàr sýnthesin kaì diaíresín esti tò pseudós te kai alethés: encobrimento, assim como descobrimento, acontece (sempre) no âmbito da junção e da separação" (ARISTÓTELES, 1844, 1, 16 a 12 apud HEIDEGGER, 1995, p. 137).

Se, com base nisso, a síntese do percebido seria sempre, simultaneamente, uma separação desse percebido, então toda percepção pressupõe necessariamente o jogo dessa articulação de duplo sentido, ou, pelo menos, resta à filosofia a tarefa da consideração da possibilidade de um noein e de noémata condizentes com essa atuação ambígua. Nesse ponto concentram-se, para Heidegger, os limites - ou as inclinações teóricas evidentes - da metafísica aristotélica, uma vez que os sentidos de ser que sua ontologia pressupõe e com os quais prioritariamente trabalha, ou seja, a presença, a unidade, o simples e eterno ser-desvelado dos princípios eternos, etc., carregariam consigo justamente uma tendência inevitável de valorização da síntese formadora da percepção (como abertura perceptiva formativa de uma unidade) em detrimento de seus aspectos disjuntores, diairéticos, ainda que estes estejam (curiosamente) contidos na apresentação formal da consumação da nóesis e explicitamente trabalhados na Ética ${ }^{23}$.

23 Não poderíamos desdobrar esse ponto neste artigo, mas entendemos que um proveitoso caminho para o aprofundamento do problema parte do seminário de inverno de 1924/25 (HEIDEGGER, 1992, p. 132-188), no qual o autor analisa longamente os motivos da colocação aristotélica da primazia da sophía, da contemplação teórica, frente às outras virtudes dianoéticas, 
Heidegger pretende, nos anos 1920, insistentemente retornar àquilo que alega ser o rico fundamento impensado de Aristóteles; no caso atual, isso pode significar pensar a partir dos gregos, mas trilhando uma direção diversa, a unidade originária do articular, da estrutura-como, como sýnthesis e diaíresis, junção $e$ separação. Vimos acima, aliás, que a cópula do 'é', expressa na predicação, é ela mesma compreendida pela tradição metafísica como uma síntese e uma síntese tal que cumpre a função de mostrar o ente nos aspectos triplos de sua essência, acidente e existência. Não estariam lançados aqui, enfim, os motivos para uma meditação do ser a partir de seus aspectos disjuntivos, retrativos e articuladores?

\section{Considerações finais}

Percorrido esse curto caminho crítico-histórico, notamos que a reflexão acerca do 'enigma' do articular da Rede, do lógos, apresenta-se como co-originária (gleich-ursprünglich) (HEIDEGGER, 2006a, §28, §34) em relação às dimensões da Erschlossenheit (Befindlichkeit e Verstehen), embora sua co-originariedade ontológica não seja encontrada exatamente na abertura de um 'âmbito' existencial próprio (a facticidade dos contextos, as afinações de humor, o possível dos projetos), mas precisamente, como entendemos, no movimento vinculativo do existir entre esses âmbitos, de modo que somente sua investigação permitiria aprofundar o problema elementar da diversidade de relações e concreções que o Dasein estabelece entre eles. Julgamos mais propriamente, aliás, que, para Heidegger, o Dasein nem ao menos estabelece relações, mas ele é sempre, em suas diversas expressividades e concreções, a relação, o articular.

Mas para que a fenomenologia possa aprofundar tal problema do relacionar, deve, segundo demos a entender a partir desta interpretação crítico-histórica bastante pontual do $\$ 33 \mathrm{em}$ seu pano de fundo, penetrar na radicalidade do problema ontológico, pois, segundo o autor, "o aclaramento do essenciar do 'como' anda ao lado da pergunta pelo essenciar do 'é', do ser. As duas perguntas servem ao desdobramento do problema do mundo" (HEIDEGGER, 2010, p. 484). Isso origina, como temos visto repetidamente, uma tentativa explícita de inserção dos aspectos retrativos, disjuntores e articuladores na abertura do Dasein, em cuja definição preliminar no $\$ 4$ de Sein und Zeit já se notava a prioridade da liberdade móvel do possível diante do simplesmente presente e atual.

em especial a phrónesis. 
Disso decorrente, também a descrição fenomenológica da abertura horizontal do ente que se dá imediatamente ao encontro no mundo (HEIDEGGER, 2006a, §§18-27) pressupõe a necessidade de abordá-lo sempre a partir do jogo (pre)-ocupado e solícito entre parte e todo, visibilidade e invisibilidade, aquisição fática de signos e possibilidade de ressignificação desses mesmos signos que traduz, enfim, a escolha cuidadosa de argumentos circulares e de um léxico baseado em estruturas 'médias', como já notava o autor, aliás, no momento de sua definição de fenômeno (HEIDEGGER, 2006a, §7). Na visão desse quadro heideggeriano como um todo percebemos a íntima ligação que o filósofo estabelece entre as tarefas da ontologia, da fenomenologia e da hermenêutica e que não poderiam ser simplificadas em uma frase, mas que dão vida às passagens decisivas de Sein und Zeit.

Retomar o problema da unidade originária da articulação da abertura como junção $e$ separação passa necessariamente, portanto, por uma crítica à ontologia da presença, à metafísica em geral como o caminho trilhado pela filosofia que tanto mais se assegura de si quanto mais abandona a meditação do ser. Isso conduzirá necessariamente à tarefa da colocação cada vez mais radical do problema da diferença ontológica entre ser e ente, entre nada e ente e entre ser e nada. Mas a fenomenologia parece mais facilmente se aproximar dos diversos modos de ser dos entes quanto menos os reduz de antemão à pura presença $\mathrm{e}$ quando não estabelece o comportamento intencional a partir do modelo teórico, presentificador de ideias. Por isso, no circular lógos hermenêutico da abertura existencial fática da práxis, a descrição do mundo (instrumentos, coisas, outros, mesmidade, etc.) parece, com grande consequência, permitir para a filosofia uma mostração não puramente positiva ou ideal.

Justamente ao manter-se na análise do espaço hermenêutico da (pre-)ocupação e solicitude práticas, enfim, Heidegger aproxima-se da possibilidade de descrição fenomenológica de uma diferenciação ontológica entre ser e ente, pois aí o ente nunca é totalmente um positum, um 'sintético' unitário pleno, uma vez que pressupõe as infinitas relativizações, contextualizações, situações, exigências imediatas, abandonos, esquecimentos, ou seja: diversos níveis de separação e disjunção. Mas naturalmente, por outro lado, também essas disjunções só podem ser o que são porque o Dasein se concretiza, se 'põe' constantemente nas ocupações do mundo. É por isso que, para o pensamento de Heidegger por volta de Sein und Zeit e segundo o interpretamos, somente a investigação fenomenológica do ser-no-mundo do ente existente - existente como possivel e como tarefa (HEIDEGGER, 2006a, §4) - poderia recolocar e repensar radicalmente a misteriosa unidade originária do noús a partir da con- 
sumação articuladora conjunta de sýnthesis e diaíresis. O âmbito de meditação da diferença ontológica é garantido como tal, logo, somente quando se introduz os modos relativizantes e finitizantes do velamento no mesmo espaço das concreções ônticas expressivas.

Diante disso poderíamos colocar, em caráter de tarefa, as perguntas, formuladas, de fato, em termos estranhos a Sein und Zeit, mas, talvez, condizentes com as perspectivas aberturas desde então pela obra de 1927 e marcantes em todos os momentos da trajetória filosófica do autor: será que o articular do Dasein em sua abertura só se explicaria quando a fenomenologia parte e se mantém no jogo ontológico entre ente e nada ou do nada como momento do ser? Como é o ser deste nada que se envolve na diferença entre ser e ente? Como é o ser para que ele possa se diferenciar?

Diante desse quadro surge eficazmente fundamentada a necessidade da retomada dos problemas da filosofia nos moldes de um novo paradigma, que possa retirar esses problemas da univocidade da metafísica da presença e meditá-los na direção de uma liberação para o pensamento do ser entre ente e nada. Heidegger insiste, por exemplo, no caminho (em parte percorrido por nós neste artigo) que começa pela crítica à lógica e aos comportamentos teóricos e que se encaminha para uma meditação radical acerca da essência da verdade. Uma vez que o acontecimento da verdade extrapola o espaço restrito do juízo, como temos visto, deve-se poder então situá-lo no âmbito pré-enunciativo da abertura. Não por acaso a primeira parte de Sein und Zeit é concluída com essa remissão programática explícita da verdade lógica para a verdade da existência. Mas isso implica certamente, do ponto de vista da crítica à tradição, um inevitável deslocamento da veritas enquanto adaequatio rei et intellectus, para a alétheia como palavra originária na qual o dogma ainda não teria eliminado, de uma vez por todas, o espaço possível de uma reflexão ontológica extrema. A título de indicação, assim justifica Heidegger, já em Sein und Zeit, a escolha dessa palavra como tópos privilegiado da meditação:

Será por acaso que os gregos se pronunciavam a respeito da essência da verdade em uma expressão privativa (a-létheia)? Não se anuncia nesse pronunciamento do Dasein uma originária compreensão ontológica de si mesmo que, contudo, constitui apenas uma compreensão pré-ontológica do fato de que o ser-na-não-verdade configura uma determinação essencial do ser-no-mundo? (HEIDEGGER, 2006a, p. 222). 
Os limites do enunciado apofântico e a posição ontológica da lógica: uma interpretação do §33 de Sein und Zeit
Dndo. Felipe Maia

da Silva [USP]

A exortação do aprofundamento da reflexão sobre o ser-na-não-verdade do Dasein é tanto pressuposto quanto consequência da presente crítica à ontologia monopolizadora do lógos e da necessidade da inversão do nexo de fundamentação, que descobre uma articulação hermenêutica de mundo mais primitiva que aquela extraída da pura análise dos juízos. Pensar a dinâmica da alétheia como acontecimento existencial do Dasein entre as concreções ônticas e as retrações no nada passará, assim, por uma retomada do problema do ser em toda sua envergadura histórica.

Mas, para aquém do problema da verdade, que agora se abre e que ecoará em toda a obra do autor, pretendíamos notar, com as últimas considerações, o sentido histórico e ontológico da crítica destrutiva do $\$ 33$ à lógica como cerceamento da potencialidade do lógos em seu modo apofântico - que se revela derivado do lógos hermenêutico. Nesse sentido talvez pudéssemos afirmar que o §32 de Sein und Zeit busca concluir a redução fenomenológica da mobilidade articuladora das 'vivências' pré-temáticas entre abertura e descoberta de mundo, remetendo, definitivamente, o ôntico ao ontológico constituinte.

O §33, por seu turno, empreende explicitamente, como vimos, uma relativa destruição fenomenológica da tradição lógico-metafísica ao indicar o sentido derivado do enunciado judicativo (onde opera o como-apofântico) justamente em relação à mobilidade da compreensibilidade (onde opera o como-hermenêutico), tornando especialmente sensível, assim, o contexto histórico e a necessidade fenomenológica de uma inversão do nexo de fundamentação. Mostramos que essa crítica agudiza, concomitantemente, o problema do ser, pois indica o vínculo entre lógica e metafísica da presença, por um lado, e verdade e existência, por outro lado. Por fim, parece pressuposta no parágrafo a tarefa filosófica de uma radicalização da exposição do lógos que possa corresponder a uma sistematização ontológica ousada e ampliadora do escopo articulador-existencial da linguagem - na medida, por exemplo, em que retoma a indicação, alegadamente presente em Aristóteles, mas por ele não levada a cabo, de uma articulação que inclua em si mesma a junção e a separação, sýnthesis e diairesis.

Julgamos, enfim, que é no $\$ 34$, cuja análise excederia as intenções deste texto, que Heidegger teria proposto finalmente certas diretivas conceituais e sistemáticas ${ }^{24}$ para o empreendimento de uma construção fenomenológica do

24 Sistemático no sentido de que é ali formalmente indicada a posição e a ordenação da fala-articuladora no âmbito de uma analítica do Dasein. Contudo, é importante que se note que a sistematicidade que se elabora mantém-se no espaço preparatório da analítica. A esse respeito uma indicação do seminário de Marburg de 1928, onde Heidegger aborda retrospectivamente 'o problema de Ser e Tempo': "contra essa analítica como um 'sistema do Dasein' encontra-se a relutância da filosofia da vida. E ela origina-se do medo do conceito e revela-se como incom- 
lógos, encontrando na investigação da Rede e da Sprache um desfecho parcial coerente com suas investigações prévias sobre o articular. Em todo caso, somente uma ampla leitura de conjunto dos três parágrafos, atenta ao caráter fenomenológico próprio da exposição, parece-nos capaz, em conclusão, de demonstrar o sentido da co-originariedade do lógos/Rede - ao lado do horizonte mundano, da disposição e do compreender - naquela analítica existencial. Os presentes esforços de nossa análise do $§ 33$ inserem-se, assim, nessa perspectiva sistemática e ampla de leitura.

preensão do conceito e da 'sistemática' - sendo, assim, uma arquitetônica própria do pensar e, contudo, histórica”. (HEIDEGGER, 1990, p. 172.)

Recebido em: 15.05.2019 | Aprovado em: 29.10.2019

ARISTÓTELES: Aristotelis Organon: Bd. 1 Hermeneutica (de interpretatione). Editor: Th. Waitz: Leipzig: 1844.

.De anima. Editor: W. Biehl: Leipzig: 1911.

HALL, H.: Intentionality and world in: The Cambridge Companion to Heidegger. Cambridge University Press: Cambridge, 1993.

HEIDEGGER, M.: Metaphysische Anfangsgründe der Logik im Ausgang von Leibniz. Frankfurt am Main: Vittorio Klostermann, 1990.

.Platon: Sophistes. Frankfurt am Main:

Vittorio Klostermann, 1992.

.Logik. Die Frage nach der Wahrheit. Frankfurt am Main: Vittorio Klostermann, 1995.

.Die Grundprobleme der Phänomenolo- gie. Frankfurt am Main: 2005.

.Sein und Zeit. $19^{a}$ edição. Tübingen: Max Niemeyer Verlag, 2006a.

.Ser e tempo. $5^{\text {a }}$ edição. Petrópolis: Editora Vozes, 2006b.

.Introdução à filosofia. 2a edição. São Paulo: Martins Fontes, 2009.

.Die Grundbegriffe der Metaphysik: Welt

- Endlichkeit - Einsamkeit. Frankfurt am Main: Vittorio Klostermann, 2010.

NUNES, B.: Passagem para o poético. $2^{\text {a }}$ edição. São Paulo: Editora Ática, 1992.

STEIN, E.: A questão do método na filosofia, um estudo do modelo heideggeriano. $2^{\text {a }}$ edição. Porto Alegre: Movimento, 1983. 
VOLPI, F.: “Das ist das Gewissen!" Heidegger interpretiert die Phronesis. in: STEINMANN, M.: Heidegger und die Griechen. Frankfurt am Main: Vittorio Klostermann, 2007.

.Heidegger y Aristóteles. Buenos Aires: Fondo de Cultura Económica, 2012.

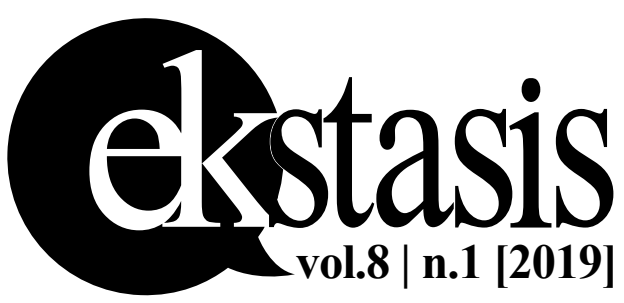

